\title{
Effect of $d$-Aldosterone on Salt and Water Absorption from the Intact Human Colon*
}

\author{
Ruven Levitan $\dagger$ and F. J. Ingelfinger \\ (From the Evans Memorial Department of Clinical Research, Massachusetts Memorial Hos- \\ pitals, Fifth and Sixth Medical Services, Boston City Hospital, and Depart- \\ ment of Medicine, Boston University School of Medicine, Boston, Mass.)
}

The primary recognized physiological action of aldosterone in man is the regulation of sodium homeostasis. This potent salt-retaining, adrenal hormone acts on the renal tubules to enhance sodium reabsorption (1-5). In addition, it has been established that aldosterone influences sodium transport in the salivary $(1,6-8)$ and sweat glands $(7,8)$.

Whether aldosterone influences sodium absorption from the human intestine has not been directly measured but has been postulated on the basis of indirect evidence and animal studies (5, 9-19). Berger and Steele (11) demonstrated that the amount of sodium removed from the gut when a cation exchange resin was fed orally was considerably less in patients with congestive heart failure and decompensated cirrhosis (both conditions in which aldosterone secretion is increased) than in normal controls. Emerson, Kahn, and Jenkins (12) showed that during continued oral binding resin therapy in subjects on a low sodium intake a gradual decline in sodium output in the stools occurred. Laragh (5) reported that aldosterone depresses the fecal $\mathrm{Na} / \mathrm{K}$ ratio. Wong, Morrison, and Hurst (14) reported similar findings after oral administration of 9-fluorohydrocortisone and in a patient with primary hyperaldosteronism.

\footnotetext{
* Submitted for publication September 29, 1964; accepted January 21, 1965.

This investigation was supported in part by U. S. Public Health Service research grants AM 03560-04 and 05 and AM 05589-02 and 03 from the National Institute of Arthritis and Metabolic Diseases.

Presented in part at the General Session, National Meeting of the American Federation for Clinical Research, Atlantic City, N. J., May 3, 1964; Clin. Res. 1964, 12, 210.

$\dagger$ Address requests for reprints to Dr. Ruven Levitan, Pratt Clinic-New England Center Hospital, 171 Harrison Avenue, Boston, Mass. 02111.
}

After adrenalectomy in rats (15) and in dogs (16), the absorption of sodium and chloride was reduced and could be restored by administration of desoxycorticosterone (17). In patients with Addison's disease, the fecal sodium loss could also be reduced by desoxycorticosterone (12). Berger, Kanzaki, and Steele showed that the rate of sodium absorption from the colon of dogs was increased after desoxycorticosterone administration (18). Shields and Elmslie (19) demonstrated an increase in potassium secretion into isolated segments of ileum and colon after intravenous administration of aldosterone to dogs. The evidence cited indicates that mineralocorticoids probably influence the fecal excretion of sodium in rats, dogs, and man.

Since a major function of the colon is sodium absorption, it seemed of interest to determine by a direct method whether aldosterone enhances sodium transport in this organ in man.

\section{Methods}

Sodium, chloride, and water absorption from the intact healthy colon was studied before and after $d$-aldosterone administration in normal volunteers who had been on a regular diet with an uncontrolled sodium intake. Their age ranged from 20 to 30 years. The technique used has been described previously (20). The cecum was intubated with an orally introduced polyvinyl tube $1.8 \mathrm{~mm}$ i.d. with a small bag containing mercury attached to its distal end. During the 3 to 4 days required for the tube to reach the colon, the subjects ingested only clear liquids and took salt as desired. All studies were performed in the recumbent position after an 8-hour fast. After the tip of the tube was localized radiologically in the cecum, a radiopaque, water-soluble solution (diatrizoate methylglucamine ${ }^{1}$ ) was instilled via the tube to ascertain whether reflux into the ileum would take place. The subjects were studied only if reflux from the cecum into the ileum was not visualized fluoroscopically.

1 Commercial name, Gastrografin, produced by E. R. Squibb and Sons, New York, N. Y. 
The colon was then cleaned thoroughly by perfusing it through the tube with $0.85 \%$ sodium chloride solution until the material expelled rectally was clear and relatively free of mucus, a process that took approximately 2 hours. After this cleansing period, 2 additional hours were allowed for the colon to become empty of the flushing solution.

After the 2-hour rest period, the test solution was infused into the cecum at a constant rate of $10 \mathrm{ml}$ per minute, and samples of the perfusate, after having traversed the entire colon, were collected through a large, multihole rectal tube (Fr. 24), the tip of which was placed approximately $8 \mathrm{~cm}$ above the anus. The test solution contained $0.85 \%$ sodium chloride and a watersoluble, nonabsorbable reference substance, polyethylene glycol (PEG) with a molecular weight of about 4,000, in a concentration of $1 \%$. Drainage from the rectal tube

\section{CONTROL ABSORPTION STUDIES}
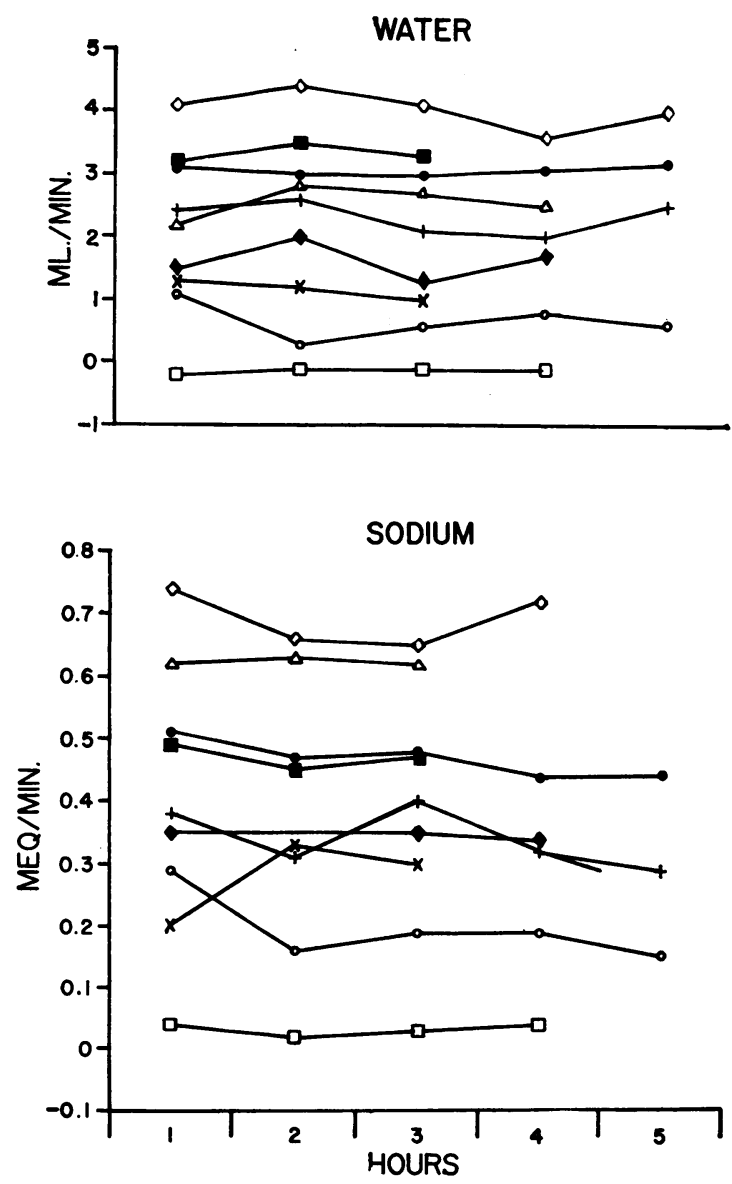

Fig. 1. Reproducibility of NET WATER AND SODIUM ABSORPTION IN NINE SUBJECTS OVER A PERIOD OF 3 TO 5 HouRs. Each point represents the value of net sodium and net water absorption over consecutive test periods of 60 minutes, respectively. was collected continuously and divided into 20-minute samples. Only those samples in which the nonabsorbable marker (PEG) concentration had achieved a steady state were used for the analysis of results. It usually took 1 hour to achieve this steady state. Each study lasted from 40 to 300 minutes after the steady state was achieved.

After a control study of at least 1 hour, $1 \mathrm{mg}$ of $d$-aldosterone, ${ }^{2}$ dissolved in $50 \mathrm{ml}$ of $5 \%$ dextrose, was administered by vein over a period of 10 to 15 minutes. In some subjects, control studies were performed for 2 consecutive days before $d$-aldosterone was given. After the injection of the hormone, the study was continued for 3 hours in seven subjects. In twelve different subjects, the study was repeated 1 day after the administration of $d$-aldosterone. Three subjects were studied 5,6 , $7,8,13,14,15,25$, and 26 hours after aldosterone was given.

Our subjects were on an unrestricted sodium intake and were additionally loaded with sodium before aldosterone administration because $a$ ) during the cleansing of the colon before the study the organ was perfused with $2,000 \mathrm{ml}$ of a $0.85 \%$ solution of $\mathrm{NaCl}$ of which about 17 to $20 \%$ is usually absorbed $(20)$ and $b$ ) on the control days before aldosterone administration, the subjects absorbed additional sodium during the test periods (a total of about $80 \mathrm{mEq}$ of sodium absorbed from the colon before aldosterone administration over and above oral intake).

Specimens obtained by the rectal tube were analyzed for PEG turbidometrically according to Hyden (21), for sodium and potassium by flame photometry (22), and for chloride by potentiometric titration (23). Osmolality was determined by freezing point depression (22). All determinations were done in duplicate.

Changes in the perfusate volume were calculated from the alterations in the concentration of the PEG (20). Net electrolyte absorption from, or secretion into, the test solution was also calculated as previously reported (20). The term "absorption" is used when the end result was a net decrease in water or electrolyte content in the perfusate, and "secretion" is used to denote a net increase in water and electrolyte content. Absorption is arbitrarily indicated by a positive $(+)$ and secretion by a negative $(-)$ sign.

The individual, spontaneous daily variations without drug administration in net sodium, chloride, and water absorption and potassium secretion were tested by variance analysis (24). Control values obtained on the day or days before $d$-aldosterone administration were compared with values obtained in the hours or days after hormone administration in the same subjects by the same statistical test. The results for all subjects before and after aldosterone were compared.

2 The $d$-aldosterone was kindly supplied by the Ciba Pharmaceutical Company, Summit, N. J., through Dr. C. H. Sullivan, Director of Clinical Investigation. 
TABLE I

Reproducibility of results*

\begin{tabular}{|c|c|c|c|c|c|c|c|}
\hline \multicolumn{2}{|c|}{ Net water absorption } & \multicolumn{2}{|c|}{ Net sodium absorption } & \multicolumn{2}{|c|}{ Net chloride absorption } & \multicolumn{2}{|c|}{ Net potassium secretion } \\
\hline First day & Second day & First day & Second day & First day & Second day & First day & Second day \\
\hline \multicolumn{2}{|c|}{$m l / m i n$} & \multicolumn{2}{|c|}{$m E q / \min$} & \multicolumn{2}{|c|}{$m E q / \min$} & \multicolumn{2}{|c|}{$m E q / \min$} \\
\hline $2.00 \pm 0.15$ & $1.98 \pm 0.30$ & $0.36 \pm 0.0$ & $0.39 \pm 0.02$ & $0.57 \pm 0.08$ & $0.54 \pm 0.09$ & $0.031 \pm 0.003$ & $0.023 \pm 0.001$ \\
\hline
\end{tabular}

* Mean results and standard error of the mean of net water, sodium, and chloride absorption and net secretion jof potassium for eleven subjects on 2 consecutive days under similar conditions. The colon was perfused at a constant rate of $10 \mathrm{ml}$ per minute with $0.85 \%$ sodium chloride solution.

\section{Results}

Reproducibility of control observations. When colonic absorption was studied as described, sodium, chloride, and water were absorbed from the test solution and potassium and bicarbonate were added to it (20).

When the study was continued for periods of 2 to 5 hours in the same subject, net sodium and water absorption remained unchanged from hour to hour as can be seen in Figure 1. When colonic absorption was studied on subsequent days under similar conditions in the same individuals, there was no over-all significant difference in absorption of sodium, chloride, and water as judged by variance analysis (see Table I). There was, however, a borderline difference in potassium secretion from day to day in the same subjects $(p=0.05)$. In addition, significant differences between subjects were observed for water, sodium, and chloride absorption $(p<0.01)$ but not for potassium sécretion.

Effect of $d$-aldosterone. Figure 2 shows the values of net sodium and water absorption over a period of 3 hours after aldosterone in seven subjects. The observed changes were not statistically significant either individually or as a group. Results obtained 24 hours after $d$-aldosterone administration are presented in Tables II, III, IV and $\mathrm{V}$, respectively.

These results (Table III) showed a statistically significant increase in sodium absorption. Similarly, net water and chloride absorption increased after aldosterone (Table II, IV). Variance analysis showed that all the observed increases are significant beyond the 0.001 level (Table VI). No significant change in potassium secretion was recorded (Tables V and VI).

Of the three subjects studied $5,6,7,8,13$, $14,15,24,25$, and 26 hours after aldosterone administration, one, number 11 (Tables II to V), did not show a change in absorption after the hormone. The second, number 12 (Tables II

TABLE II

Influence of d-aldosterone on net water absorption*

\begin{tabular}{|c|c|c|c|}
\hline \multirow[b]{2}{*}{ Subject } & \multicolumn{2}{|c|}{$\begin{array}{l}\text { Net water absorption } \\
\text { Before aldosterone }\end{array}$} & \multirow{2}{*}{$\begin{array}{l}\text { After aldosterone } \\
\text { One day }\end{array}$} \\
\hline & Two days & One day & \\
\hline & $m l / m i n$ & $m l / \min$ & $m l / \min$ \\
\hline 1 & & $\begin{array}{c}0.87 \pm 0.35 \\
(\mathrm{n}=3)\end{array}$ & $\begin{array}{c}2.20 \pm 0.20 \\
(\mathrm{n}=3)\end{array}$ \\
\hline 2 & & $\begin{array}{c}0.27 \pm 0.23 \\
(\mathrm{n}=3)\end{array}$ & $\begin{array}{c}2.10 \pm 0.90 \\
(n=4)\end{array}$ \\
\hline 3 & & $\begin{array}{c}3.70 \pm 1.40 \\
(n=3)\end{array}$ & $\begin{array}{c}7.00 \pm 0.70 \\
(\mathrm{n}=3)\end{array}$ \\
\hline 4 & $\begin{array}{c}3.50 \pm 0.60 \\
(\mathrm{n}=4)\end{array}$ & $\begin{array}{c}2.10 \pm 0.40 \\
(\mathrm{n}=7)\end{array}$ & $\begin{array}{c}2.80 \pm 0.50 \\
(n=5)\end{array}$ \\
\hline $4 a$ & $\begin{array}{c}2.00 \pm 0.50 \\
(\mathrm{n}=5)\end{array}$ & $\begin{array}{c}2.20 \pm 1.50 \\
(\mathrm{n}=3)\end{array}$ & $\begin{array}{c}3.86 \pm 0.60 \\
(\mathrm{n}=5)\end{array}$ \\
\hline 5 & $\begin{array}{c}0.10 \pm 0.40 \\
(n=3)\end{array}$ & $\begin{array}{c}1.10 \pm 0.50 \\
(\mathrm{n}=3)\end{array}$ & $\begin{array}{c}0.85 \pm 0.70 \\
(\mathrm{n}=4)\end{array}$ \\
\hline 6 & $\begin{array}{c}2.10 \pm 0.40 \\
\quad(n=3)\end{array}$ & $\begin{array}{c}1.60 \pm 0.80 \\
(\mathrm{n}=3)\end{array}$ & $\begin{aligned} & 3.60 \pm 0.60 \\
&(n=8)\end{aligned}$ \\
\hline 7 & $\begin{array}{c}2.90 \pm 0.60 \\
(\mathrm{n}=3)\end{array}$ & $\begin{array}{c}4.10 \pm 0.20 \\
(n=6)\end{array}$ & $\begin{array}{c}6.80 \pm 0.20 \\
(n=3)\end{array}$ \\
\hline 8 & $\begin{array}{c}3.20 \pm 0.10 \\
(\mathrm{n}=3)\end{array}$ & $\begin{array}{c}2.40 \pm 1.10 \\
(\mathrm{n}=4)\end{array}$ & $\begin{array}{c}4.70 \pm 0.40 \\
(n=6)\end{array}$ \\
\hline 9 & & $\begin{array}{c}1.00 \pm 0.60 \\
(\mathrm{n}=8)\end{array}$ & $\begin{array}{c}3.40 \pm 0.30 \\
(\mathrm{n}=3)\end{array}$ \\
\hline 10 & & $\begin{array}{c}3.40 \pm 0.60 \\
(\mathrm{n}=4)\end{array}$ & $\begin{array}{c}3.00 \pm 0.40 \\
(\mathrm{n}=7)\end{array}$ \\
\hline 11 & $\begin{array}{c}2.95 \pm 0.77 \\
(\mathrm{n}=4)\end{array}$ & $\begin{array}{c}2.87 \pm 0.52 \\
(n=6)\end{array}$ & $\begin{array}{c}4.41 \pm 0.38 \\
(\mathrm{n}=7)\end{array}$ \\
\hline 12 & & $\begin{array}{c}3.55 \pm 0.20 \\
(n=4)\end{array}$ & $\begin{array}{c}4.26 \pm 0.42 \\
(\mathrm{n}=7)\end{array}$ \\
\hline $\begin{array}{l}\text { Mean of } \\
\text { entire } \\
\text { group } \\
\pm S E\end{array}$ & $2.39 \pm 0.21$ & $2.24 \pm 0.36$ & $3.77 \pm 0.14$ \\
\hline
\end{tabular}

* Mean results $\pm \mathrm{SD}$ of net water absorption on control day or days and 24 hours after $d$-aldosterone administration. The colon was perfused at a constant rate of $10 \mathrm{ml}$ per minute with $0.85 \%$ sodium chloride solution. Standard deviation is not given unless the results for at least three study periods are available. The number of consecutive test periods ( $n$ ) is indicated. Each test period lasted 20 minutes. 
to $\mathrm{V}$ ), showed a significant increase in water, sodium, and chloride absorption 24 hours after aldosterone but not earlier. The results of sodium and water absorption in the third subject are shown in Figure 3.

As can be seen, sodium absorption started to rise significantly 7 hours after aldosterone injection and reached a peak between the eighth and thirteenth hours. A significant water absorption rise was documented 6 hours after injection with the peak occurring between the eighth and thirteenth hours.

TABLE III

Influence of $d$-aldosterone on net sodium absorption*

\begin{tabular}{|c|c|c|c|}
\hline \multirow[b]{2}{*}{ Subject } & \multicolumn{2}{|c|}{$\begin{array}{c}\text { Net sodium absorption } \\
\text { Before aldosterone }\end{array}$} & \multirow{2}{*}{$\begin{array}{l}\text { After aldosterone } \\
\text { One day }\end{array}$} \\
\hline & Two days & One day & \\
\hline 1 & $m E q / \min$ & $\begin{array}{c}m E q / \min \\
0.17 \pm 0.06 \\
(\mathrm{n}=3)\end{array}$ & $\begin{array}{c}m E q / \min \\
0.40 \pm 0.20 \\
(\mathrm{n}=3)\end{array}$ \\
\hline 2 & & $\begin{array}{c}0.07 \pm 0.04 \\
(\mathrm{n}=3)\end{array}$ & $\begin{array}{c}0.39 \pm 0.11 \\
(\mathrm{n}=4)\end{array}$ \\
\hline 3 & & $\begin{array}{c}0.62 \pm 0.21 \\
(\mathrm{n}=3)\end{array}$ & $\begin{array}{c}1.13 \pm 0.10 \\
(\mathrm{n}=3)\end{array}$ \\
\hline 4 & $\begin{array}{l}0.54 \pm 0.08 \\
(\mathrm{n}=4)\end{array}$ & $\begin{array}{c}0.50 \pm 0.18 \\
(\mathrm{n}=7)\end{array}$ & $\begin{array}{c}0.49 \pm 0.07 \\
(\mathrm{n}=5)\end{array}$ \\
\hline $4 a$ & $\begin{array}{c}0.35 \pm 0.07 \\
(n=5)\end{array}$ & $\begin{array}{c}0.36 \pm 0.14 \\
(\mathrm{n}=3)\end{array}$ & $\begin{array}{c}0.69 \pm 0.11 \\
(\mathrm{n}=5)\end{array}$ \\
\hline 5 & $\begin{array}{c}0.10 \pm 0.03 \\
(\mathrm{n}=3)\end{array}$ & $\begin{array}{c}0.12 \pm 0.06 \\
(n=3)\end{array}$ & $\begin{array}{l}0.57 \pm 0.08 \\
(\mathrm{n}=4)\end{array}$ \\
\hline 6 & $\begin{array}{c}0.40 \pm 0.06 \\
(\mathrm{n}=3)\end{array}$ & $\begin{array}{c}0.29 \pm 0.14 \\
(\mathrm{n}=3)\end{array}$ & $\begin{array}{c}0.58 \pm 0.07 \\
(\mathrm{n}=3)\end{array}$ \\
\hline 7 & $\begin{array}{c}0.72 \pm 0.04 \\
(n=3)\end{array}$ & $\begin{array}{l}0.73 \\
\quad(n=2)\end{array}$ & $\stackrel{1.12}{(n=2)}$ \\
\hline 8 & $\begin{array}{c}0.63 \pm 0.02 \\
(n=3)\end{array}$ & $\begin{array}{c}0.51 \pm 0.15 \\
(\mathrm{n}=4)\end{array}$ & $\begin{array}{c}0.68 \pm 0.06 \\
(n=6)\end{array}$ \\
\hline 9 & & $\begin{array}{c}0.24 \pm 0.10 \\
(\mathrm{n}=3)\end{array}$ & $\begin{array}{c}0.58 \pm 0.04 \\
(\mathrm{n}=3)\end{array}$ \\
\hline 10 & & $\begin{array}{c}0.66 \pm 0.04 \\
(n=4)\end{array}$ & $\begin{array}{c}0.60 \pm 0.05 \\
(\mathrm{n}=3)\end{array}$ \\
\hline 11 & $\begin{array}{c}0.56 \pm 0.05 \\
(n=4)\end{array}$ & $\begin{array}{c}0.49 \pm 0.10 \\
(n=6)\end{array}$ & $\begin{array}{l}0.72 \pm 0.04 \\
(\mathrm{n}=7)\end{array}$ \\
\hline 12 & & $\begin{array}{c}0.52 \pm 0.06 \\
(\mathrm{n}=4)\end{array}$ & $\begin{array}{c}0.71 \pm 0.11 \\
(\mathrm{n}=7)\end{array}$ \\
\hline $\begin{array}{l}\text { Mean of } \\
\text { entire } \\
\text { group } \\
\pm S E\end{array}$ & $0.47 \pm 0.033$ & $0.41 \pm 0.032$ & $0.67 \pm 0.012$ \\
\hline
\end{tabular}

* Mean results $\pm 1 \mathrm{SD}$ of net sodium absorption on control day or days and 24 hours after $d$-aldosterone administration. The colon was perfused at a constant rate of 10 ml per minute with $0.85 \%$ sodium chloride solution. Standard deviation is not given unless the results for at least three study periods are available. The number of consecutive test periods ( $\mathrm{n}$ ) is indicated. Each test period lasted 20 minutes.

\section{Discussion}

The administration of $d$-aldosterone intravenously in the amount of $1 \mathrm{mg}$ to healthy young men on an unrestricted sodium intake was not followed by a significant rise in net sodium and water absorption within 3 hours after injection.

The increase in net sodium and water absorption 24 hours after aldosterone, however, was statistically highly significant with $\mathrm{p}$ values of $<0.001$. Differences between control days are consistently insignificant. Those between control days and test days, on the other hand, differ at

TABLE IV

Influence of d-aldosterone on net chloride absorption*

\begin{tabular}{|c|c|c|c|}
\hline \multirow[b]{2}{*}{ Subject } & \multicolumn{2}{|c|}{$\begin{array}{c}\text { Net chloride absorption } \\
\text { Before aldosterone }\end{array}$} & \multirow{2}{*}{$\begin{array}{l}\text { After aldosterone } \\
\text { One day }\end{array}$} \\
\hline & Two days & One day & \\
\hline 1 & $m E q / \min$ & $\begin{array}{c}m E q / \min \\
0.47 \pm 0.03 \\
(\mathrm{n}=3)\end{array}$ & $\begin{array}{c}m E q / \min \\
0.57 \pm 0.03 \\
(\mathrm{n}=3)\end{array}$ \\
\hline 2 & & $\begin{array}{c}0.18 \pm 0.09 \\
(\mathrm{n}=3)\end{array}$ & $\begin{array}{c}0.43 \pm 0.14 \\
(\mathrm{n}=4)\end{array}$ \\
\hline 3 & & $\begin{array}{c}0.84 \pm 0.18 \\
(n=3)\end{array}$ & $\begin{array}{c}1.14 \pm 0.72 \\
(n=3)\end{array}$ \\
\hline 4 & $\begin{array}{l}0.62 \pm 0.070 \\
(\mathrm{n}=3)\end{array}$ & $\begin{array}{c}0.61 \pm 0.10 \\
(\mathrm{n}=7)\end{array}$ & $\begin{array}{c}0.62 \pm 0.06 \\
(\mathrm{n}=5)\end{array}$ \\
\hline $4 a$ & $\begin{array}{l}0.54 \pm 0.050 \\
\quad(n=5)\end{array}$ & $\begin{array}{c}0.68 \pm 0.08 \\
(\mathrm{n}=3)\end{array}$ & $\begin{array}{c}0.81 \pm 0.12 \\
(\mathrm{n}=3)\end{array}$ \\
\hline 5 & $\begin{array}{l}0.31 \pm 0.002 \\
(\mathrm{n}=3)\end{array}$ & $\begin{array}{c}0.40 \pm 0.08 \\
(\mathrm{n}=3)\end{array}$ & $\begin{array}{c}0.38 \pm 0.09 \\
(\mathrm{n}=4)\end{array}$ \\
\hline 6 & $\begin{array}{l}0.70 \pm 0.030 \\
(\mathrm{n}=3)\end{array}$ & $\begin{array}{c}0.62 \pm 0.08 \\
(\mathrm{n}=3)\end{array}$ & $\begin{array}{c}0.80 \pm 0.07 \\
(\mathrm{n}=8)\end{array}$ \\
\hline 7 & $\begin{array}{l}0.84 \pm 0.100 \\
(\mathrm{n}=3)\end{array}$ & $\begin{array}{c}0.96 \pm 0.03 \\
(n=6)\end{array}$ & $\stackrel{1.18}{(n=2)}$ \\
\hline 8 & $\begin{array}{l}0.78 \pm 0.020 \\
\quad(n=3)\end{array}$ & $\begin{array}{c}0.77 \pm 0.14 \\
(\mathrm{n}=4)\end{array}$ & $\begin{array}{c}0.88 \pm 0.05 \\
(n=6)\end{array}$ \\
\hline 9 & & $\begin{array}{c}0.47 \pm 0.09 \\
(n=8)\end{array}$ & $\begin{array}{c}0.85 \pm 0.05 \\
(n=3)\end{array}$ \\
\hline 10 & & $\begin{array}{l}0.72 \pm 0.05 \\
(\mathrm{n}=4)\end{array}$ & $\begin{array}{c}0.67 \pm 0.05 \\
(\mathrm{n}=3)\end{array}$ \\
\hline 11 & $\begin{array}{l}0.76 \pm 0.040 \\
(\mathrm{n}=4)\end{array}$ & $\begin{array}{c}0.65 \pm 0.10 \\
(\mathrm{n}=6)\end{array}$ & $\begin{array}{c}1.01 \pm 0.13 \\
(n=7)\end{array}$ \\
\hline 12 & & $\begin{array}{c}0.68 \pm 0.03 \\
(n=4)\end{array}$ & $\begin{array}{c}1.00 \pm 0.25 \\
(\mathrm{n}=7)\end{array}$ \\
\hline $\begin{array}{l}\text { Mean of } \\
\text { entire } \\
\text { group } \\
\pm \mathrm{SE}\end{array}$ & $0.65 \pm 0.042$ & $0.62 \pm 0.017$ & $0.79 \pm 0.057$ \\
\hline
\end{tabular}

* Mean results $\pm 1 \mathrm{SD}$ of net chloride absorption on control day or days and 24 hours after $d$-aldosterone administration. The colon was perfused at a constant rate of $10 \mathrm{ml}$ per minute with $0.85 \%$ sodium chloride solution. Standard deviation is not given unless the results for at least three study periods are available. The number of consecutive test periods $(n)$ is indicated. Each test period lasted 20 minutes. 


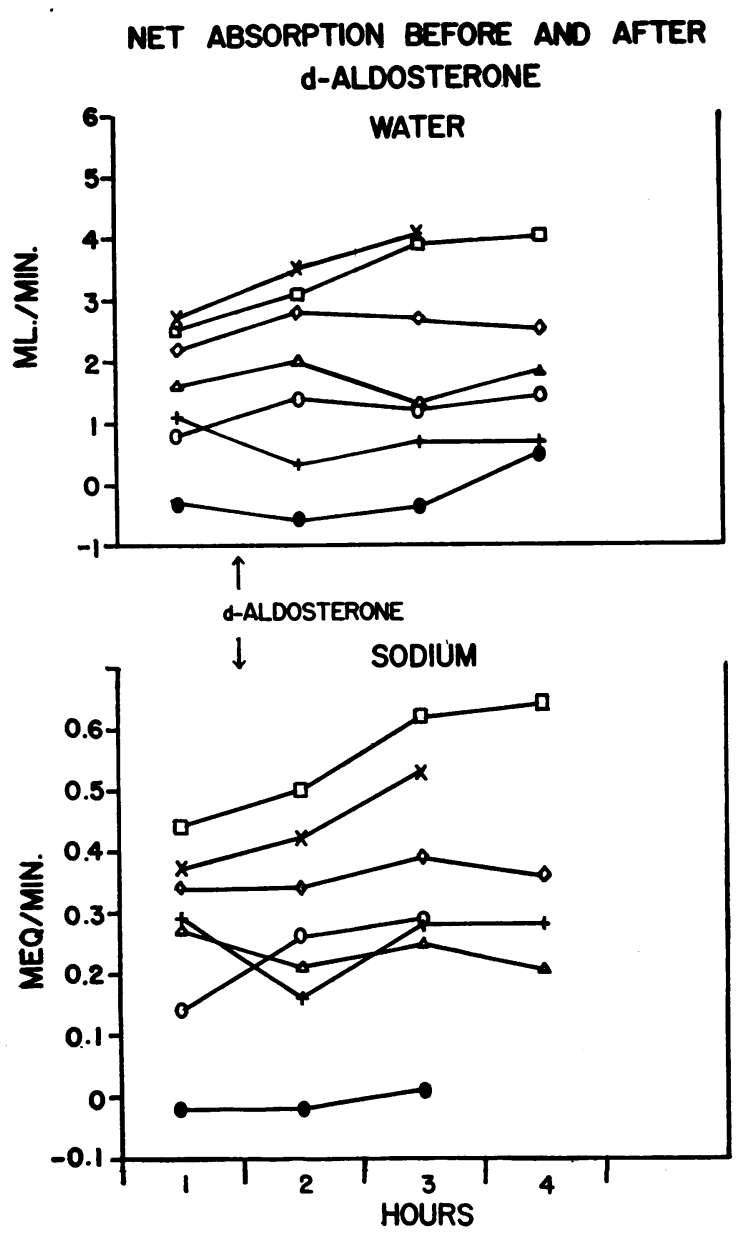

Fig. 2. INFLUENCE OF D-ALDOSTERONE ON NET WATER AND SODIUM ABSORPTION IN SEVEN SUBJECTS. The hormone was administered intravenously at the time indicated by the arrow. The values left from the arrow indicate the control data and the ones right from the arrow, the results at consecutive hourly intervals after aldosterone.
TABLE V

Influence of d-aldosterone on net potassium secretion*

\begin{tabular}{|c|c|c|c|}
\hline \multirow[b]{2}{*}{ Subject } & \multicolumn{2}{|c|}{$\begin{array}{l}\text { Net potassium secretion } \\
\text { Before aldosterone }\end{array}$} & \multirow{2}{*}{$\begin{array}{l}\text { After aldosterone } \\
\text { One day }\end{array}$} \\
\hline & Two days & One day & \\
\hline 1 & $m E q / \min$ & $\begin{array}{c}m E q / \min \\
0.023 \pm 0.003 \\
(n=3)\end{array}$ & $\begin{array}{c}m E q / \min \\
0.031 \pm 0.007 \\
(\mathrm{n}=3)\end{array}$ \\
\hline 2 & & $\begin{array}{l}0.018 \pm 0.006 \\
(n=3)\end{array}$ & $\begin{array}{l}0.038 \pm 0.005 \\
(n=4)\end{array}$ \\
\hline 3 & & $\begin{array}{c}0.017 \pm 0.004 \\
(n=3)\end{array}$ & $\begin{array}{c}0.015 \pm 0.001 \\
(n=3)\end{array}$ \\
\hline 4 & $\begin{array}{l}0.030 \pm 0.000 \\
(\mathrm{n}=3)\end{array}$ & $\begin{array}{l}0.040 \pm 0.010 \\
(\mathrm{n}=7)\end{array}$ & $\begin{array}{l}0.020 \pm 0.005 \\
(\mathrm{n}=5)\end{array}$ \\
\hline $4 a$ & $\begin{array}{l}0.028 \pm 0.005 \\
(\mathrm{n}=5)\end{array}$ & $\begin{array}{l}0.029 \pm 0.011 \\
(\mathrm{n}=3)\end{array}$ & $\begin{array}{l}0.017 \pm 0.002 \\
(\mathrm{n}=5)\end{array}$ \\
\hline 5 & $\begin{array}{l}0.040 \pm 0.020 \\
\quad(n=3)\end{array}$ & $\begin{array}{l}0.010 \pm 0.010 \\
(n=3)\end{array}$ & $\begin{array}{l}0.025 \pm 0.010 \\
(n=4)\end{array}$ \\
\hline 6 & $\begin{array}{l}0.027 \pm 0.003 \\
(\mathrm{n}=3)\end{array}$ & $\begin{array}{l}0.032 \pm 0.005 \\
\quad(\mathrm{n}=3)\end{array}$ & $\begin{array}{c}0.016 \pm 0.002 \\
(\mathrm{n}=8)\end{array}$ \\
\hline 7 & $\begin{array}{l}0.020 \\
\quad(\mathrm{n}=2)\end{array}$ & $\begin{array}{l}0.030 \pm 0.017 \\
(n=6)\end{array}$ & $\begin{array}{l}0.026 \pm 0.008 \\
(\mathrm{n}=3)\end{array}$ \\
\hline 8 & $\begin{array}{l}0.022 \pm 0.010 \\
\quad(\mathrm{n}=3)\end{array}$ & $\begin{array}{l}0.025 \pm 0.005 \\
\quad(n=4)\end{array}$ & $\begin{array}{c}0.016 \pm 0.006 \\
(n=6)\end{array}$ \\
\hline 9 & & $\begin{array}{l}0.032 \pm 0.005 \\
\quad(n=8)\end{array}$ & $\begin{array}{l}0.021 \pm 0.003 \\
(n=3)\end{array}$ \\
\hline 10 & & $\begin{array}{l}0.023 \pm 0.004 \\
\quad(n=4)\end{array}$ & $\begin{array}{l}0.032 \pm 0.001 \\
(\mathrm{n}=3)\end{array}$ \\
\hline 11 & $\begin{array}{l}0.029 \pm 0.003 \\
(\mathrm{n}=4)\end{array}$ & $\begin{array}{l}0.013 \pm 0.003 \\
(n=6)\end{array}$ & $\begin{array}{c}0.024 \pm 0.010 \\
(\mathrm{n}=7)\end{array}$ \\
\hline 12 & & $\begin{array}{l}0.030 \pm 0.004 \\
(\mathrm{n}=4)\end{array}$ & $\begin{array}{c}0.026 \pm 0.020 \\
(\mathrm{n}=7)\end{array}$ \\
\hline $\begin{array}{l}\text { Mean of } \\
\text { entire } \\
\text { group } \\
\pm S E\end{array}$ & $0.028 \pm 0.001$ & $0.025 \pm 0.001$ & $0.024 \pm 0.000$ \\
\hline
\end{tabular}

* Mean results $\pm 1 \mathrm{SD}$ of net potassium secretion on control day or days and 24 hours after $d$-aldosterone administration. The colon was perfused at a constant rate of $10 \mathrm{ml}$ per minute with $0.85 \%$ sodium chloride solution. Standard deviation is not given unless the results for at least three study periods are available. The number of consecutive test periods $(n)$ is indicated. Each test period lasted 20 minutes.

TABLE VI

Variance analysis of results presented in Tables II to $V$ : comparison of absorption before and after d-aldosterone*

\begin{tabular}{lccccc}
\hline \hline & DF & $\begin{array}{c}\text { Net water } \\
\text { absorption } \\
\text { F }\end{array}$ & $\begin{array}{c}\text { Net sodium } \\
\text { absorption } \\
\text { F }\end{array}$ & $\begin{array}{c}\text { Net chloride } \\
\text { absorption } \\
\text { F }\end{array}$ & $\begin{array}{c}\text { Net potassium } \\
\text { absorption } \\
\text { F }\end{array}$ \\
\hline Subjects & 12 & $6.5606 \dagger$ & $6.3507 \dagger$ & $9.0962 \dagger$ & 0.5375 \\
$\begin{array}{l}\text { Drug effect } \\
\text { REM }\end{array}$ & 12 & $25.0521 \dagger$ & $32.7910 \dagger$ & $19.3942 \dagger$ & 0.1125 \\
SE of reading & 12 & \pm 0.7766 & \pm 0.1158 & \pm 0.1020 & \pm 0.0089 \\
\hline
\end{tabular}

* Subjects = variability between subjects; drug effect = variability after drug as compared to control values; $\mathrm{REM}=$ unaccountable variability; $\mathrm{DF}=$ degrees of freedom; $\mathrm{F}=\mathrm{Fischer}$ ratio.

† Significant difference at 0.01 level or better.

† Standard errors of individual readings. 


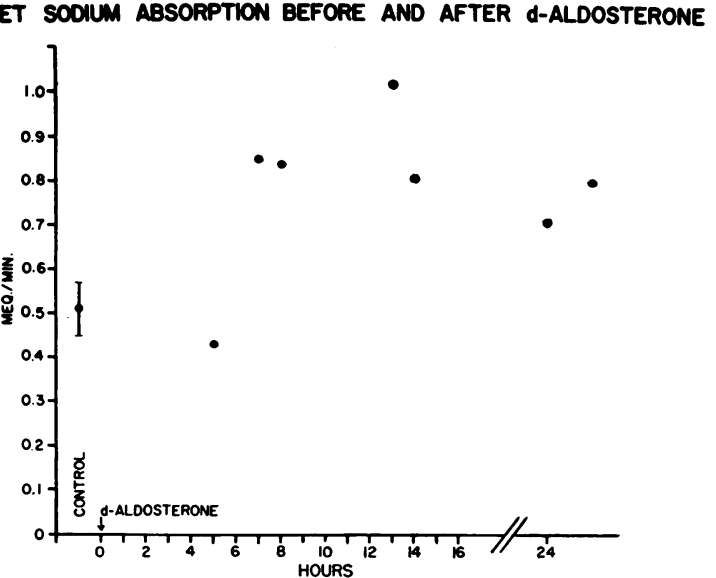

NET WATER ABSORPTION BEFORE AND AFTER d-ALDOSTERONE

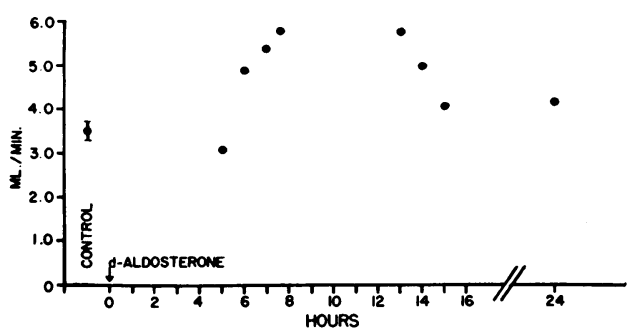

Fig. 3. REsults of NET SODIUM AND WATER ABSORPTION AFTER D-ALDOSTERONE IN ONE SUBJECT STUDIED 5, 6 , $7,8,13,14,15$, AND 24 HOURS AFTER INJECTION.

a very high level of significance (except for potassium). This seems to leave no doubt that the differences in absorption are associated with the administration of aldosterone. Under the circumstances, no injections of placebos were given.

We would like to suggest that the observed increase in sodium absorption from the colon is due to the direct action of aldosterone on this organ. An alternative explanation, however, might be that aldosterone acts on another organ, i.e., the kidney, which in turn, in some fashion, affects the colonic permeability. Such an interpretation of our results cannot be excluded on the basis of our observations.

Our findings do not indicate the time at which the peak effect of aldosterone on the human colon occurs or when a significant change in absorption begins. The studies performed in three subjects $5,7,8,13,14,15,24,25,26$ hours after the hormone administration suggest that the magnitude and time of aldosterone effect on the colon are variable. In one sequential study, sodium ab- sorption started to rise significantly 7 hours after aldosterone and reached a peak between 8 and 13 hours.

The effect of aldosterone on sodium transport in the colon was more delayed than the effect observed by others on the human kidney (25). Sonnenblick, Cannon, and Laragh (25) documented an aldosterone effect on the kidney as early as 20 to 60 minutes after intravenous administration of $2 \mathrm{mg}$ of $d, l$-aldosterone monoacetate; the peak of this effect occurred 2 to 4 hours after injection. The depressed sodium chloride excretion by the kidney did not return toward the control values until 6 to 8 hours after completion of aldosterone administration (25). This difference between the colon and kidney in the latent period after aldosterone administration is interesting in the light of recent evidence suggesting that the aldosterone-induced increase in $\mathrm{Na}^{+}$transport requires the de novo synthesis of nucleoproteins (26). Perhaps the different time response of the colon to aldosterone as compared to the kidney reflects the different rates of protein synthesis in these two organs. It is also possible that the large amounts of aldosterone we employed might have a glucocorticoid effect that is detectable 24 hours after administration.

The fact that potassium loss from the colon did not increase after aldosterone is noteworthy. This observation is in agreement with findings in other systems in which aldosterone may have an independent effect on sodium and potassium transport $(25,27)$.

Our data show that the colon, as has been postulated $(5,9,11,14)$, can be influenced by aldosterone as are many other biological systems. Our data, however, do not indicate whether aldosterone plays an important regulatory role in sodium absorption from the colon under conditions of normal production rates of this hormone by the adrenal because the amount of $d$ aldosterone given to our subjects $(1 \mathrm{mg})$ greatly exceeded the amount of aldosterone elaborated by normal subjects ( $150 \mu \mathrm{g}$ to $300 \mu \mathrm{g}$ per day) (28). On the other hand, the amount of hormone we gave is less than the aldosterone secretion in decompensated cirrhosis $(2,000$ to 3,000 $\mu \mathrm{g}$ per day) or nephrosis (up to $6,600 \mu \mathrm{g}$ per day) (29) and is similar to that secreted in preg- 
nant women (about $1,000 \mu \mathrm{g}$ per day) (28), in normal subjects under conditions of sodium deprivation (29), and in some patients with malignant hypertension and primary aldosteronism (30). Hence, it would be reasonable to suggest that, in clinical conditions associated with diarrhea in which daily aldosterone production rates are increased, the colon may be influenced by this hormone and this may moderate the intestinal loss of sodium.

\section{Summary}

Net sodium, chloride, and water absorption from the human colon before and after intravenous administration of $1 \mathrm{mg}$ of $d$-aldosterone was studied in 12 healthy, recumbent subjects on an unrestricted salt intake. A test solution containing $0.85 \%$ sodium chloride was infused into the cecum at a constant rate of $10 \mathrm{ml}$ per minute. A nonabsorbable reference substance, polyethylene glycol, in the concentration of $1 \%$ was added to the test solution in order to measure water absorption. The test solution that had traversed the entire colon was collected by a rectal tube.

A significant increase $(\mathrm{p}<0.001)$ in the sodium absorption was observed 24 hours after aldosterone administration. Similarly, net chloride and net water absorption also increased ( $p$ $<0.001)$.

Twenty-four hours after aldosterone administration, the mean net absorption of sodium for the entire study group rose from $0.41 \mathrm{mEq}$ per minute to $0.67 \mathrm{mEq}$ per minute; chloride rose from $0.62 \mathrm{mEq}$ per minute to $0.79 \mathrm{mEq}$ per minute; and water from $2.24 \mathrm{ml}$ per minute to $3.77 \mathrm{ml}$ per minute. No significant increase in potassium secretion was observed.

Our studies suggest that the colon, like other sodium-transporting systems, is influenced by aldosterone. Unlike other biological systems, however, the aldosterone effect on the human colon was not noted within 3 hours but was evident 24 hours after administration.

\section{Acknowledgments}

We thank Dr. Hugo Muench and Miss Rasma Klints, consultants in Biostatistics, Lemuel Shattuck Hospital, for their help in statistical analysis.

\section{References}

1. Mach, R. S., J. Fabre, A. Duckert, R. Borth, and P. Ducommun. Action clinique et metabolique de l'aldosterone (electrocortine). Schweiz. med. Wschr. 1954, 84, 407.

2. August, J. T., D. H. Nelson, and G. W. Thorn. Response of normal subjects to large amounts of aldosterone. J. clin. Invest. 1958, 37, 1549.

3. Bartter, F. C., I. H. Mills, E. G. Biglieri, and C. Delea. Studies on the control and physiologic action of aldosterone. Recent Progr. Hormone Res. 1959, 15, 311.

4. Davis, J. O. Some aspects of the physiology of aldosterone. J. nat. med. Ass. (N. Y.) 1957, 49, 42.

5. Laragh, J. H. Aldosterone in fluid and electrolyte disorders: hyper- and hypoaldosteronism. J. chron. Dis. 1960, 11, 292.

6. Simpson, S. A., and J. F. Tait. Some recent advances in methods of isolation, chemistry and physiology of aldosterone. Recent Progr. Hormone Res. 1955, 11, 183.

7. Conn, J. W. Primary aldosteronism, a new clinical syndrome. J. Lab. clin. Med. 1955, 45, 3.

8. Conn, J. W. Primary aldosteronism. J. Lab. clin. Med. 1955, 45, 661.

9. Ganz-Borek, C., and C. A. M. Hogben. An action in vitro of adrenal corticosteroids upon fluid movement across the isolated intestinal epithelium. Physiologist 1960, 3, 64.

10. Duncan, L. E., Jr., G. W. Liddle, and F. C. Bartter. The effect of changes in body sodium on extracellular fluid volume and aldosterone and sodium excretion by normal and edematous men. J. clin. Invest. 1956, 35, 1299.

11. Berger, E. Y., and J. M. Steele. Suppression of sodium excretion by the colon in congestive heart failure and cirrhosis of the liver demonstrated by the use of cation exchange resins. J. clin. Invest. 1952, 31, 451.

12. Emerson, K., Jr., S. S. Kahn, and D. Jenkins. The role of the gastro-intestinal tract in the adaptation of the body to the prevention of sodium depletion by cation exchange resins. Ann. N. Y. Acad. Sci. 1953, 57, 280.

13. Berger, E. Y., G. P. Quinn, and M. A. Homer. Effect of desoxycorticosterone on the colon: its relation to the action of cation exchange resins in man. Proc. Soc. exp. Biol. (N. Y.) 1951, 76, 601.

14. Wong, O., R. B. Morrison, and P. E. Hurst. A method of obtaining freal fluid by in-vivo dialysis. Lancet 1961, 1, 1208.

15. Clark, W. G. Effect of adrenalectomy upon intestinal absorption of sodium chloride. Proc. Soc. exp. Biol. (N. Y.) 1939, 40, 468.

16. Dennis, C., and E. H. Wood. Intestinal absorption in adrenalectomized dog. Amer. J. Physiol. 1940, 129, 182. 
17. Stein, L., and E. Wertheimer. Effect of adrenalectomy on intestinal absorption involving osmotic work in rats. Proc. Soc. exp. Biol. (N. Y.) 1941, 46, 172.

18. Berger, E. Y., G. Kanzaki, and J. M. Steele. The effect of desoxycorticosterone on the undirectional transfers of sodium and potassium into and out of the dog intestine. J. Physiol. (Lond.) 1960, 151, 352.

19. Shields, R., and R. G. Elmslie. The effect of aldosterone on absorption of water and electrolytes from the ileum and colon of the dog. Brit. J. Surg. 1962, 50, 96.

20. Levitan, R., J. S. Fordtran, B. A. Burrows, and F. J. Ingelfinger. Water and salt absorption in the human colon. J. clin. Invest. 1962, 41, 1754.

21. Hyden, S. A turbidometric method for determination of higher polyethylene glycols in biological materials. Ann. roy. Agr. Coll. Sweden 1955, 22, 139.

22. Annino, J. S. Clinical Chemistry, Principles and Procedures, 2nd ed. Boston, Little, Brown, 1960, p. 99.

23. Sanderson, P. H. Potentiometric determination of chloride in biological fluids. Biochem. J. 1952, 52, 502.
24. Snedecor, G. W. Statistical Methods Applied to Experiments in Agriculture and Biology, 5th ed. Ames, Iowa, The Iowa State College Press, 1956.

25. Sonnenblick, E. H., P. J. Cannon, and J. H. Laragh. The nature of the action of intravenous aldosterone: evidence for a role of the hormone in urinary dilution. J. clin. Invest. 1961, 40, 903.

26. Edelman, I. S., R. Bogoroch, and G. A. Porter. On the mechanism of action of aldosterone on sodium transport: the role of protein synthesis. Proc. nat. Acad. Sci. (Wash.) 1963, 50, 1169.

27. Williamson, H. E. Mechanism of the antinatriuretic action of aldosterone. Biochem. Pharmacol. 1963, $12,1449$.

28. Watanabe, M., C. I. Meeker, M. J. Gray, E. A. H. Sims, and S. Solomon. Secretion rate of aldosterone in normal pregnancy. J. clin. Invest. 1963, 42, 1619.

29. Ulick, S., J. H. Laragh, and S. Lieberman. Isolation of a urinary metabolite of aldosterone and its use to measure the rate of secretion of aldosterone by the adrenal cortex of man. Trans. Ass. Amer. Phycns. 1958, 71, 225.

30. Laragh, J. H., S. Ulick, V. Januszewicz, Q. B. Deming, W. G. Kelly, and S. Lieberman. Aldosterone secretion and primary and malignant hypertension. J. clin. Invest. 1960, 39, 1091. 